\title{
Evolution of the Orapa A/K1 Geology Model - Insights from Analysis of Multi-Disciplinary Datasets
}

\author{
Kganetso Maphane \\ Debswana, Orapa Mine, kmaphane2@debswana.bw
}

\section{Introduction}

The Cretaceous Orapa A\K1 is exposed as a bilobate kimberlite pipe with preserved crater lithofacies. The pipe is currently the biggest of all known kimberlite bodies within the Orapa Kimberlite Cluster $(\mathrm{OKC})$, covering a surface area of $\sim 118$ hectares. A number of these kimberlite bodies are currently being economically exploited (e.g. Orapa A/K1, Damtshaa B/K9 \& B/K11, and Letlhakane D/K1 \& $\mathrm{D} / \mathrm{K} 2$ ) or at advanced evaluation stage (e.g. A/K20). Mining activities in the Orapa area started in 1971 after discovery of the A/K1 kimberlite in 1967.

Following discovery, a number of resource evaluations were conducted and subsequently five geological models generated (Table 1). These models improved with time as the geology of the pipe is exposed through mining, and as more drilling targeting deeper levels were completed. The purpose of this document is to summarise the evolution of the geological models including data input informing the models.

\section{Historical Work}

The initial stage of evaluation included shallow pitting to a depth of $30 \mathrm{~m}$ for grade determination, and a limited core drilling to define the pipe shape. This work focused on the sedimentology of the preserved crater in-fill exposed in the pit and intersected by pitting and core drilling. The result of the pitting exercise was the generation of the first model for planning purposes in the late 1970's and later updated after additional drilling and mapping in 1991. Since much of the mining was in the crater, an extensive work on the preserved fossils in the fossil shale basin was completed. This work included description and dating of the fossils by Rayner and McKay (1987) where they interpreted the paleo Orapa climate as strongly seasonal, with a warm wet summer and dry cold winter. It was during this early work that a strong correlation between lithofacies type and diamond grade was established in the Orapa A/K1 (e.g. Minter, 1978; Dobbs, 1980).

Table 1: Evolution of the Orapa A/K1 Geological Model

\begin{tabular}{|c|c|c|c|c|c|c|}
\hline & $1967-1980$ & 1982-1993 & 1993-1997 & 2006-2007 & 2006-2009 & 2010-2014 \\
\hline Evaluation Program & \begin{tabular}{|}
$250 \mathrm{Ft}$ grid pit \\
sampling to $120 \mathrm{Ft}$ \\
50 core drill, \\
$<100 \mathrm{~m}$ depth
\end{tabular} & $\begin{array}{c}526 \text { LDD jumper } \\
\text { holes on 50m } \\
\text { grid, Max depth of } \\
260 \mathrm{mbgl}\end{array}$ & $\begin{array}{c}\text { Deep contact \& } \\
\text { geotech drilling, } 66 \\
\text { core holes, Max } \\
\text { depth of } 600 \mathrm{mbgl}\end{array}$ & $\begin{array}{l}\text { Special project } \\
\text { commisioned to update } \\
\text { A/K1 geological model } \\
\text { (no new drilling) }\end{array}$ & $\begin{array}{c}\text { OREP Phase } 1 \text { Contact drilling, } \\
99 \text { holes }(\sim 38000 \mathrm{~m}) \text {. Max } \\
\text { depth of } 900 \mathrm{mbgl}\end{array}$ & \begin{tabular}{|c|} 
OREP Phase 2 Grade Sampling \\
(215 core holes at $50 * 50 \mathrm{~m}$ grid - \\
$72000 \mathrm{~m})$ and Revenue sampling \\
$(20$ LDD holes $-9100 \mathrm{~m}) \mathrm{Max}$ \\
depth $475 \mathrm{mbgl}$
\end{tabular} \\
\hline Geology Model & \begin{tabular}{|c|} 
First A/K1 ore \\
reserve $(0-30 \mathrm{mbgl})$ \\
Dobbs $(1978)$
\end{tabular} & Shaw (1991) & $\begin{array}{c}1^{\text {st }} \text { Digital detailed 3- } \\
\text { D model (Field } \\
1997 \text { ) }\end{array}$ & $\begin{array}{c}2^{\text {nd }} \text { 3-D Model (Maccelari } \\
\text { \& Farrow 2007) }\end{array}$ & $\begin{array}{c}3^{\text {rd }} \text { (Letsatle } 2009 \text { \& Tait } \\
2010)\end{array}$ & $4^{\text {th }} \& 5^{\text {th }}($ Sejoe $2012 \& 2013)$ \\
\hline
\end{tabular}

\section{Recent Work}

Between the year 1982 and 1997, another core drilling project was initiated targeting the resource at depth. It was after this project that the first digital geological model for $\mathrm{A} / \mathrm{K} 1$ was developed by Field (1997), incorporating all historical data and information from resource evaluations, geotechnical drilling and mapping. Field (1997) proposed an update of classification scheme during this work which modified the existing schemes used during the course of evaluation and mining of the A/K1. Field (1997) was able to produce an extremely detailed lithofacies analysis of the various rock-types present in $\mathrm{A} / \mathrm{K} 1$, subdividing lithofacies on the basis of internal structure, composition (mineralogy) and texture. Much of this work became instrumental in devising the kimberlite nomenclature scheme of 
Field and Scott-Smith (1999), highlighting the relevance and quality of this work. This model is currently considered comprehensive and accepted as the basis for the A/K1 conceptual model.

More additional drill core and large diameter sampling was later completed between 2006 and 2014 (e.g. OREP1 and 2), and following this work, a series of updated three dimensional geological models were produced (see Table 1). Detailed geological description of the model based on massive semiquantitative data generated from (e.g. geochemistry-bulk rock XRF, spinel mineral chemistry, microdiamonds, internal lithic content, lithic size, mantle xenocrysts and ore dressing studies) to augment physical observations was documented. Comments on the emplacement mechanism were also updated in light of recent advancements in kimberlite volcanology. In the A/K1 North Pipe, two new lithofacies (MVK2 and NPK_GG) were added into the internal geology of the pipe. In the A/K1 South Pipe, a new pyroclastic kimberlite (SPK) was added.

It was during the OREP sampling program that extensive geochemical and spinels groundmass analysis (Stiefenhofer 2011 and Field 2015) were conducted for the major rock types in the A/K1. The geochemical analysis completed by Stiefenhofer (2009) concluded that the North and South Pipe major units geochemical signatures were distinct, potentially suggesting different magma sources for the two pipes. This conclusion was tested in Stiefenhofer (2011), and later updated by Field (2015) through spinel groundmass sampling analysis (e.g. $\mathrm{Fe}^{2+} /\left(\mathrm{Fe}^{2+}+\mathrm{Mg}\right), \mathrm{Cr} /(\mathrm{Cr}+\mathrm{Al}), \mathrm{Ti} /(\mathrm{Ti}+\mathrm{Cr}+\mathrm{Al})$ and $\left.\mathrm{Fe}^{3+} /\left(\mathrm{Fe}^{3+}+\mathrm{Cr}+\mathrm{Al}\right)\right)$ where it was further concluded that the South Pipe have near identical compositions and differs from the North Pipe lithologies. The spinel data for North Pipe, although overlapping across the three main geological lithologies, are statistically different suggesting different magma source. Concurrent with analysis of the geochemistry, continuous country-rock xenoliths dilution $(+5 \mathrm{~mm})$, type and size were analysed and subsequently a 3-D dilution model generated from the data. This data was crucial in identification of individual units and gradational contacts across geological units (Figure 1).

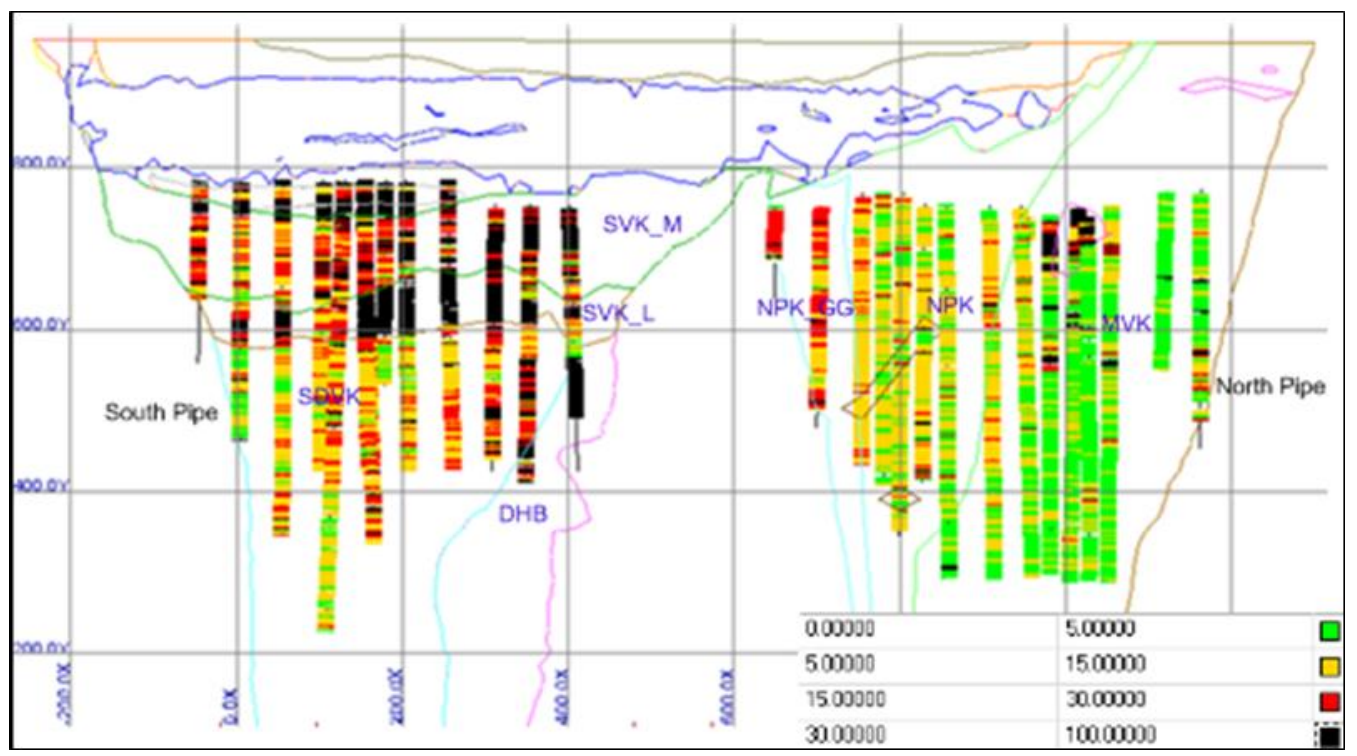

Figure 1: A section showing the crustal dilution distribution across the A/K1 Pipe.

Apart from the above internal studies, De Beers collaborated with external institutions to study and understand the geology of the A/K1. In 2009, Gernon et al. (2009a) applied field mapping data to reconstruct the internal stratigraphy of the A/K1 crater. Additional work by Gernon et al. (2009b) summarized the occurrence of a pyroclastic flow deposit in the A/K1 South Pipe which was suggested to be an infill deposits from another nearby kimberlite eruption. Fontana et al. (2008) collected numerous lithic clasts from within the $\mathrm{A} / \mathrm{K} 1$ deposits to assess the variations in emplacement temperature of various internal units, by measuring the thermo-remnant magnetism within clasts. This study has demonstrated the vast difference in emplacement temperatures within deposits of A/K1. 


\section{Conclusion}

An understanding of the geology of the A/K1 kimberlite has improved significantly since the first model was produced, particularly at depth, where additional drill holes have permitted a far better constraint on the stratigraphy of the deposits. The application of continuous downhole dilution effectively distinguished the complex geology of the pipe and has formed the basis for the current model of Sejoe (2013).

\section{References}

Dobbs, P.N., 1980. The relationship between diamond grade and sedimentary facies at Orapa. Internal De Beers (Botswana) Mining Company Report

Field, M., 1997. A geological model of 2125/AK1. Internal Debswana Company Report

Field, M., Scott Smith, B.H., 1999. Textural and genetic classification schemes for kimberlites: a new perspective. 7th International Kimberlite Conference, Cape Town, South Africa, Extended Abstracts, pp 214-216

Field, M., 2015. Groundmass spinel- Orapa North Pipe constrains on geological model OREPII Botswana

Fontana G, Mac Niocaill C, Brown RJ, Sparks RSJ, Field M., 2011. Emplacement temperatures of pyroclastic and volcaniclastic deposits in kimberlite pipes in southern Africa. Bull Volcanol 73:1063-1083

Gernon, T.M., Field, M. Sparks, R.S.J. 2009a. Depositional processes in a kimberlite crater: The Upper Cretaceous Orapa South Pipe (Botswana)

Gernon, T.M., Fontana, G., Field, M., Sparks, R.S.J., Brown, R.J., Mac Niocaill, C., 2009b. Pyroclastic flow deposits from a kimberlite eruption: The Orapa South Crater, Botswana

Minter, W.E.L., 1978. The nature and economic significance of sediments in the Orapa Crater, DEBOT Report, Record Number: 5124

Rayner, R.J., Mckay, I. J., 1987. The treasure chest of the Orapa Diamond Mine

Sejoe, T., 2014. 3-Dimensional Geological Model of the A/K1 Kimberlite Resource. Orapa: Debswana Orapa and Letlhakane Mines.

Stiefenhofer, J., 2009. Analysis of the geochemical, crustal dilution and clast size data from the Orapa Resource Extension Project (OREP), Botswana. Internal DBGS_MRM report prepared for Debswana

Stiefenhofer, J., 2011. Analysis of the spinel groundmass data from the Orapa Resource Extension Project (OREP), Botswana-implication for the South Lobe Geological model update 